\title{
Visible-light-promoted Decarboxylation of Carboxylic Acids by A Supramolecular Complex Based on Ruthenium(II) and Copper(II)
}

\author{
Mengying Zhao a, Yanxu Zhang ${ }^{b}$ and Duobin Chao c, * \\ School of Petroleum and Chemical Engineering, Dalian University of Technology, Panjin 124221, \\ China. \\ a374763490@qq.com, bzhangyanxu@mail.dlut.edu.cn, cchao11359@sina.com
}

Keywords: Ruthenium, Copper, Photocatalysis, Decarboxylation.

\begin{abstract}
A supramolecular complex containing one ruthenium(II) center ( $\mathrm{Ru}_{\text {chro }}{ }^{\mathrm{II}}$ ) and two copper(II) centers $\left(\mathrm{Cu}_{\text {cat }}^{\mathrm{II}}\right)$ has been prepared facilely. The complex was employed for decarboxylation of carboxylic acids with molecular oxygen $\left(\mathrm{O}_{2}\right)$ under visible-light irradiation, resulting in aldehydes. The photocatalytic reactions proceeded successfully in the presence of $\mathrm{O}_{2}$ without extra sacrificial reagents. It was found that an electron transfer from excited state of chromophore $\mathrm{Ru}^{\mathrm{II} *}$ chro to $\mathrm{Cu}_{\text {cat }}^{\mathrm{II}}$ occurred along with generation of $\mathrm{Cu}_{\text {cat }}^{\mathrm{I}}$ which was further activated by $\mathrm{O}_{2}$. These results demonstrate a promising strategy for photocatalytic reactions using supramolecular complexes in the presence of $\mathrm{O}_{2}$.
\end{abstract}

\section{Introduction}

Transition metal complexes are of significance in the photocatalytic reactions under solar irradiation.[1] Besides mononuclear metal complexes, supramolecular complexes known as chromophore-catalyst assemblies are widely employed for various photocatalytic processes.[2] These assemblies commonly contain a light-absorbing chromophore such as $\left[\mathrm{Ru}(\mathrm{bpy})_{3}\right]^{2+}$ and a catalytic site such as high-valent metal-oxo species $\mathrm{Ru}^{\mathrm{IV}}(\mathrm{O})$. [3] They are usually used in the presence of sacrificial electron donors such as triethanolamine (TEOA) or electron acceptors such as $\mathrm{S}_{2} \mathrm{O}_{8}{ }^{2-}$. Sacrificial reagents are necessary and essential to fulfill the whole catalytic cycle. However, sacrificial reagents are converted to useless byproducts and also enhance complexity of reactions. For instance, the electron acceptor $\mathrm{S}_{2} \mathrm{O}_{8}{ }^{2-}$ in photocatalytic water oxidation can influence decomposition of catalyst and chromophore.[4] Therefore, a light-driven catalytic cycle without sacrificial reagents would be appealing. On the other hand, molecular oxygen $\left(\mathrm{O}_{2}\right)$ is routinely excluded to achieve good catalytic performance in many photocatalytic reactions. $\mathrm{O}_{2}$ is known as a green and abundant oxidant. In nature, $\mathrm{O}_{2}$ is capable of participating redox processes by activating metal center of various enzymes. [5] Inspired by these enzymes, great efforts have been devoted to developing efficient aerobic catalysis.[6] Aerobic reactions under visible light irradiation are attractive and transition metal complexes have been employed for aerobic photocatalytic reactions.[7] Nevertheless, it is highly desirable to develop efficient and selective oxidation of substrates using $\mathrm{O}_{2}$. Although copper compounds have been widely utilized in aerobic reactions due to facile accessibility of versatile copper oxidation states, high turnover number (TON) in catalysis through durable cycle of redox couple $\mathrm{Cu}^{\mathrm{I}} / \mathrm{Cu}^{\mathrm{II}}$ is challenging under mild conditions. [8] Durable cycle of $\mathrm{Cu}^{\mathrm{I}} / \mathrm{Cu}^{\mathrm{II}}$ under mild conditions may be realized upon light irradiation as demonstrated in other photogenerated cycle of metal sites. Therefore, to develop a more efficient and promising photocatalytic system, we expect a light-driven catalytic process in which conventional sacrificial reagents are absent and $\mathrm{O}_{2}$ acts as the clean oxidant to activate metal sites using a supramolecular complex. 


\section{Results and Discussion}

\subsection{Synthesis and characterization of supramolecular complex}

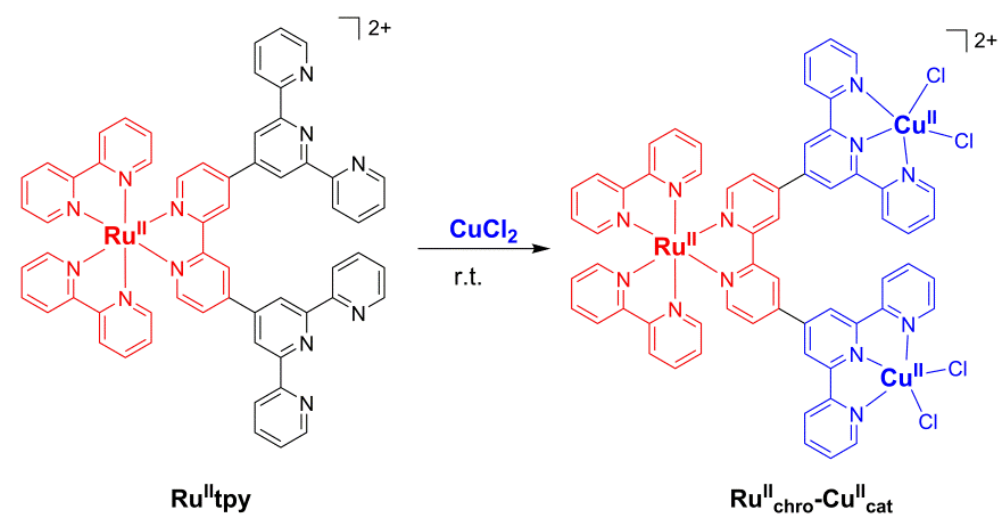

Scheme 1. Preparation of the assembly RuIIchro-CuIIcat by RuIItpy and $\mathrm{CuCl} 2$ at room temperature

In this study, a supramolecular chromophore-catalyst assembly (abbreviated as $\mathrm{Ru}_{\text {chro }}^{\mathrm{II}}-\mathrm{Cu}_{\text {cat }}^{\mathrm{II}}$ ) was prepared as a proof of concept for light-driven reactions with $\mathrm{O}_{2}$ (Scheme 1). The assembly contains a $\left[\mathrm{Ru}(\mathrm{bpy})_{3}\right]^{2+}$ unit as the light-absorbing chromophore and two $[\mathrm{Cu}(\text { tpy })]^{2+}$ (tpy $=2,2^{\prime}: 6^{\prime}, 2^{\prime \prime}-$ terpyridine) groups as catalytic sites. High resolution electrospray ionization mass spectrometry (HR-ESI-MS) was carried out to confirm the structure of $\mathrm{Ru}^{\mathrm{II}}{ }_{\text {chro }}-\mathrm{Cu}_{\text {cat. }}^{\mathrm{II}}$. As shown in Figure 1, the signal peak at 649.0004 $\mathrm{m} / \mathrm{z}$ (calcd. 649.0022) is assigned to $[M]^{2+}\left(M=\mathrm{Ru}_{\text {chro }}^{\mathrm{II}}-\mathrm{Cu}_{\text {cat }}^{\mathrm{II}}\right)$, and the isotope signal interval is around 0.5 , which is in consistent with its two positive charges.

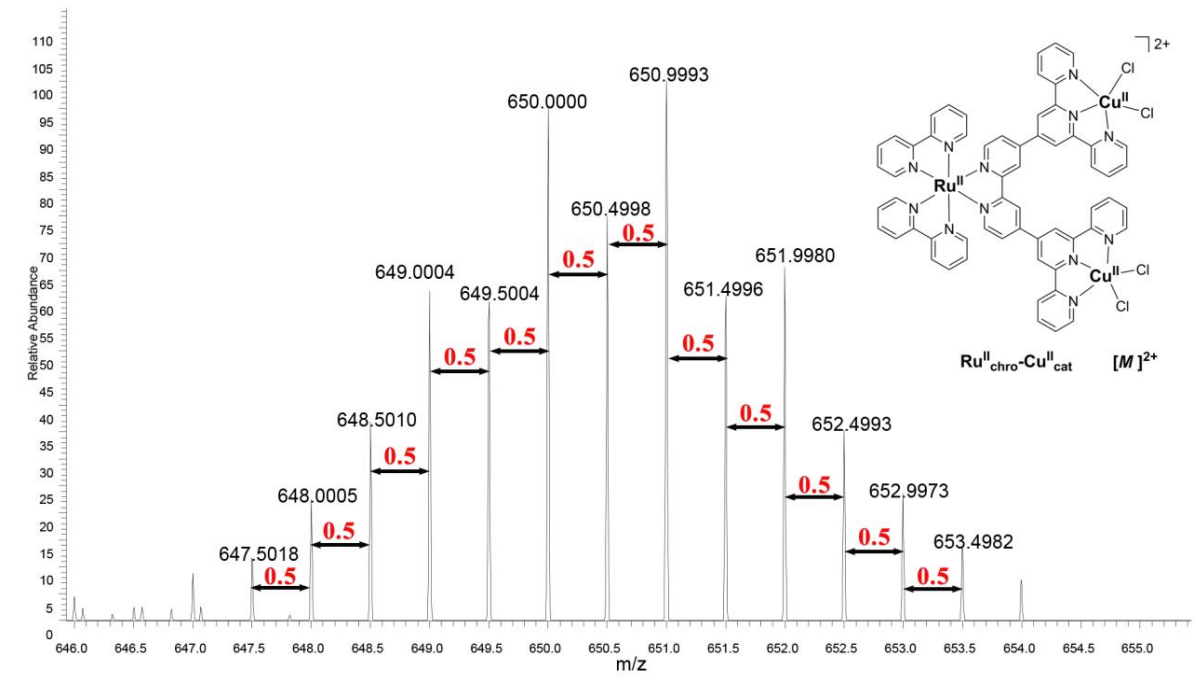

Figure 1. Partial HR-ESI-MS spectrum of RuIIchro-CuIIcat for [M]2+.

\subsection{Photocatalytic decarboxylation of carboxylic Acids}

To confirm photocatalytic performance of $\mathrm{Ru}^{\mathrm{II}}$ chro $-\mathrm{Cu}_{\text {cat }}^{\mathrm{II}}$, we further employed $\mathrm{Ru}^{\mathrm{II}}{ }_{\text {chro }}-\mathrm{Cu}^{\mathrm{II}}$ cat in the light-driven decarboxylation of carboxylic acids in the presence of $\mathrm{O}_{2}$. The reaction of $\mathrm{Ru}^{\mathrm{II}}{ }_{\text {chro }}-\mathrm{Cu}^{\mathrm{II}}$ cat and 4-methoxyphenylacetic acid was initially studied and carried out in $6 \mathrm{~mL} \mathrm{CH}{ }_{3} \mathrm{CN} / \mathrm{H}_{2} \mathrm{O}(\mathrm{V} / \mathrm{V}, 5 / 1$, $\mathrm{pH}=8.5)$ solution containing $\mathrm{Ru}^{\mathrm{II}}{ }_{\text {chro }}-\mathrm{Cu}^{\mathrm{II}}{ }_{\text {cat }}(20 \mathrm{uM})$ and 4-methoxyphenylacetic acid $(40 \mathrm{mM})$ under irradiation with blue LEDs and an oxygen atmosphere supplied by a balloon. The solution was stirred at room temperature for $18 \mathrm{~h}$. 4-methoxybenzaldehyde was found after extraction with $\mathrm{CH}_{2} \mathrm{Cl}_{2}$ and quantified by ${ }^{1} \mathrm{H}$ NMR. From the ${ }^{1} \mathrm{H}$ NMR spectrum, we could not find significant chemical shifts of other compounds, suggesting high selectivity of this light-driven process. The turnover numbers (TONs) were calculated to be 650 (Table 1, entry 1). Lower TONs were observed when $\mathrm{O}_{2}$ was replaced by air (Table 1, entry 2). However, no 4-methoxybenzaldehyde was detected when the solution was irradiated under $\mathrm{N}_{2}$ (Table 1, entry 3). These results strongly indicate that $\mathrm{O}_{2}$ is essential for this photocatalytic process. In addition, when $\mathrm{Ru}^{\mathrm{II}}{ }_{\text {chro }}-\mathrm{Cu}_{\text {cat }}^{\mathrm{II}}$ was replaced by its separated components $\mathrm{Ru}^{\mathrm{II}}{ }_{\text {chro }}$ and $\mathrm{Cu}^{\mathrm{II}}$ cat, 
only trace of 4-methoxybenzaldehyde was observed and TONs were calculated to be 30 (Table 1, entry 4). This low efficiency was probably due to poor electron transfer from separated $\mathrm{Ru}_{\text {chro }}^{\mathrm{II}}$ to $\mathrm{Cu}^{\mathrm{II}}$ cat as observed in other chromophore-catalyst systems. It is noteworthy that no product was found when $\mathrm{Ru}_{\text {chro }}^{\mathrm{II}}$ or $\mathrm{Cu}_{\text {cat }}^{\mathrm{II}}$ was used separately (Table 1 , entries 5 and 6 ). This highlights the cooperative interaction between $\mathrm{Ru}_{\text {chro }}^{\mathrm{II}}$ and $\mathrm{Cu}_{\text {cat }}^{\mathrm{II}}$. Further control experiment showed no product without irradiation, indicating the whole process was induced by light irradiation. We found the UV-vis absorption spectrum after irradiation was nearly identical to that before irradiation, suggesting the assembly was very stable in the reaction conditions. Other carboxylic acids were similarly converted to corresponding aldehydes (Table 2, entries 1 and 2). Although preparation of aldehydes through $\mathrm{Ru}_{\text {chro }}^{\mathrm{II}}-\mathrm{Cu}_{\text {cat }}^{\mathrm{II}}$ seemed to be complicated, these results demonstrate its photocatalytic activity in the presence of $\mathrm{O}_{2}$.

Table 1. Photocatalytic decarboxylation of 4-methoxyphenylacetic acid a

\begin{tabular}{|c|c|c|c|}
\hline Entry & Catalyst & Atmosphere & TON[d] \\
\hline 1 & RuIIchro-CuIIcat & O2 & 650 \\
\hline 2 & RuIIchro-CuIIcat & air & 340 \\
\hline 3 & RuIIchro-CuIIcat & N2 & 0 \\
\hline $4 b$ & RuIIchro + CuIIcat & O2 & 30 \\
\hline 5 & RuIIchro & O2 & 0 \\
\hline $6 c$ & CuIIcat & CH & 0 \\
\hline
\end{tabular}

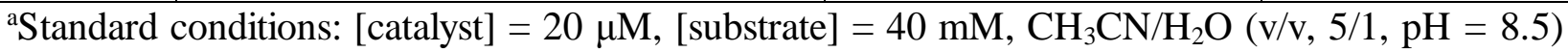
solution, room temperature and blue LEDs irradiation $(450 \pm 10 \mathrm{~nm}, 3 \mathrm{~W})$ for $18 \mathrm{~h} .{ }^{b} \mathbf{R} \mathbf{u}_{\text {chro }}^{\mathrm{II}}=$

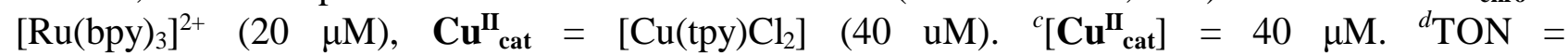
$\mathrm{n}$ (product)/n(catalyst).

Table 2. Photocatlytic decarboxylation of carboxylic acids and oxidation of sulfides using

RuIIchro-CuIIcat with O2

\begin{tabular}{|c|c|c|c|}
\hline Entry & Substrate & Product & $\mathrm{TONb}(\mathrm{t} / \mathrm{h})$ \\
\hline $1 \mathrm{a}$ & & & $563(18)$ \\
\hline $2 \mathrm{a}$ & & & $420(18)$ \\
\hline $3 a$ & & & $650(18)$ \\
\hline
\end{tabular}

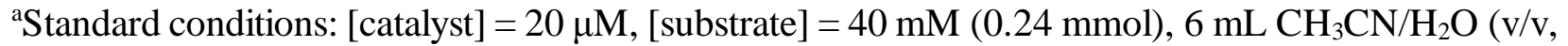
$5 / 1, \mathrm{pH}=8.5)$ solution, room temperature and blue LEDs irradiation $(450 \pm 10 \mathrm{~nm}, 3 \mathrm{~W})$ under $\mathrm{O}_{2}$ for 18 h. ${ }^{b}$ TON $=\mathrm{n}$ (product) $/ \mathrm{n}$ (catalyst).

\subsection{Photocatalytic mechanism}

According to the above results and previous studies, we proposed a possible mechanism for decarboxylation of carboxylic acids and oxidation of sulfides using assembly $\mathrm{Ru}_{\text {chro }}^{\mathrm{II}}-\mathrm{Cu}_{\text {cat }}^{\mathrm{II}}$ (Scheme 2 ). First, $\mathrm{Ru}^{\mathrm{II}}$ chro is excited to $\mathrm{Ru}^{\mathrm{II}} *_{\text {chro }}$ under light irradiation. Then an electron transfer from $\mathrm{Ru}^{\mathrm{II}} *_{\text {chro }}$ to $\mathrm{Cu}_{\text {cat }}^{\mathrm{II}}$ occurs and $\mathrm{Cu}_{\text {cat }}^{\mathrm{II}}$ is reduced to $\mathrm{Cu}_{\text {cat }}^{\mathrm{I}}$ along with generation of $\mathrm{Ru}^{\mathrm{III}}{ }_{\text {chro }}-\mathrm{Cu}_{\text {cat. }}^{\mathrm{I}} \mathrm{Ru}^{\mathrm{III}}$ chro has moderate oxidation ability and can oxidize carboxylate anions. As a result, $\mathrm{Ru}^{\mathrm{III}}$ chro is reduced to $\mathrm{Ru}^{\mathrm{II}}$ chro along with generation of $\mathrm{Ru}_{\text {chro }}^{\mathrm{II}}-\mathrm{Cu}_{\text {cat }}^{\mathrm{I}}$ which is emissive under $\mathrm{N}_{2}$ atmosphere. However, $\mathrm{Cu}_{\text {cat }}^{\mathrm{I}}$ is oxidized to $\mathrm{Cu}^{\mathrm{II}}$ cat and activated by $\mathrm{O}_{2}$, resulting in emission quenching and an copper-oxygen adduct $\mathrm{Ru}_{\text {chro }}^{\mathrm{II}}-\mathrm{Cu}^{\mathrm{II}}$ cat $\left(\mathrm{O}_{2}\right)$. Then, as shown in Scheme $2, \mathrm{Ru}_{\text {chro }}^{\mathrm{II}}-\mathrm{Cu}^{\mathrm{II}}{ }_{\text {cat }}\left(\mathrm{O}_{2}\right)$ probably return to $\mathrm{Ru}^{\mathrm{II}}$ chro $-\mathrm{Cu}^{\mathrm{II}}$ cat through reduction of oxygen and formation of water in the photocatalytic decarboxylation of carboxylic acids. Carbon-centered radical resulted from oxidation of $\mathrm{RCOO}^{-}$reacted with molecular $\mathrm{O}_{2}$ and produce corresponding aldehydes. As a sequence, a light-driven catalytic cycle without sacrificial reagents is realized. 


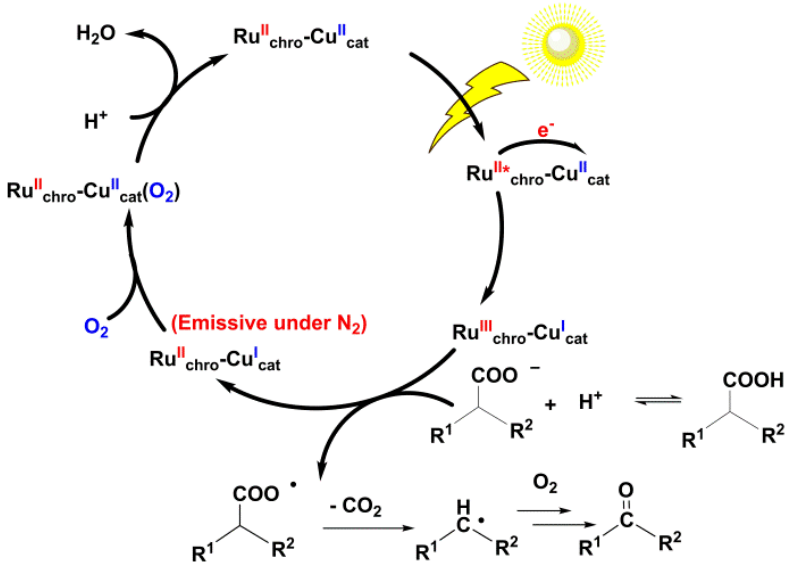

Scheme 2. Proposed mechanism for photocatalytic oxidation of sulfides using RuIIchro-CuIIcat with $\mathrm{O} 2$.

\section{Summary}

In summary, we have successfully prepared a supramolecular chromophore-catalyst assembly $\mathrm{Ru}_{\text {chro }} \mathrm{Cu}_{\text {cat }} \mathrm{Cu}^{\mathrm{II}}$ for photocatalytic decarboxylation of carboxylic acids with molecular $\mathrm{O}_{2}$. The whole catalytic process proceeded without extra sacrificial reagents. It is demonstrated that an electron transfer from excited chromophore $\mathrm{Ru}^{\mathrm{II} *}$ chro to catalytic unit $\mathrm{Cu}_{\text {cat }}^{\mathrm{II}}$ occurred along with generation of $\mathrm{Cu}_{\text {cat }}^{\mathrm{I}}$ which was activated by $\mathrm{O}_{2}$. Carboxylic acids were converted to aldehydes through decarboxylation with TONs up to 650 . The cooperative catalysis using a light-absorbing chromophore ( $\mathrm{Ru}^{\mathrm{II}}$ chro) and an $\mathrm{O}_{2}$-binding catalytic site $\left(\mathrm{Cu}_{\text {cat }}^{\mathrm{II}}\right)$ provides a useful strategy for light-driven processes with $\mathrm{O}_{2}$.

\section{References}

[1]. Corrigan, N.; Shanmugam, S.; Xu, J.; Boyer, C. Photocatalysis in organic and polymer synthesis. Chem. Soc. Rev. Vol. 45 (2016) No. 22, p. 6165-6212.

[2]. Mulfort, K. L.; Utschig, L. M. Modular Homogeneous Chromophore-Catalyst Assemblies. Acc. Chem. Res. Vol. 49 (2016), No. 5, p. 835-843.

[3]. Fukuzumi, S. Electron transfer and catalysis with high-valent metal-oxo complexes. Dalton Trans. Vol. 44 (2015), No. 15, p. 6696-6705.

[4]. Limburg, B.; Bouwman, E.; Bonnet, S. Rate and Stability of Photocatalytic Water Oxidation using [Ru(bpy)3]2+ as Photosensitizer. ACS Catal. Vol. 6 (2016), No. 8, p. 5273-5284.

[5]. Liu, J.; Chakraborty, S.; Hosseinzadeh, P.; Yu, Y.; Tian, S.; Petrik, I.; Bhagi, A.; Lu, Y. Metalloproteins containing cytochrome, iron-sulfur, or copper redox centers. Chem. Rev. Vol. 114 (2014), No. (8), p. 4366-4469.

[6]. Roux, Y.; Ricoux, R.; Avenier, F.; Mahy, J.-P. Bio-inspired electron-delivering system for reductive activation of dioxygen at metal centres towards artificial flavoenzymes. Nat. Commun. Vol. 6 (2015), p. 8509.

[7]. Jung, J.; Neu, H. M.; Leeladee, P.; Siegler, M. A.; Ohkubo, K.; Goldberg, D. P.; Fukuzumi, S. Photocatalytic Oxygenation of Substrates by Dioxygen with Protonated Manganese(III) Corrolazine. Inorg. Chem. Vol. 55 (2016), No. 7, p. 3218-3228.

[8]. Iali, W.; Lanoe, P.-H.; Torelli, S.; Jouvenot, D.; Loiseau, F.; Lebrun, C.; Hamelin, O.; Ménage, S. A Ruthenium(II)-Copper(II) Dyad for the Photocatalytic Oxygenation of Organic Substrates Mediated by Dioxygen Activation. Angew. Chem. Int. Ed. Vol. (54) 2015, No. 29, p. 8415-8419. 